ORIGINAL ARTICLE

AFRICAN JOURNAL OF CLINICAL AND EXPERIMENTAL MICROBIOLOGY

AJCEM/21309
COPYRIGHT 2013

MAY $2013 \quad$ ISBN 1595-689X VOL 14(2) 2013

-http://www.aiol.info/iournals/aicem

AFR. J. CLN. EXPER. MICROBIOL 14(2): 45-50 http://dx.doi.org/10.4314/ajcem.v14i2.1

\title{
THE USE OF MORPHOLOGICAL AND CELL WALL CHEMICAL MARKERS IN THE IDENTIFICATION OF STREPTOMYCES SPECIES ASSOCIATED WITH ACTINOMYCETOMA
}

\author{
Mohamed E. Hamid \\ Department of Clinical Microbiology and Parasitology, College of Medicine, King Khalid University Po Box 641, \\ Abha 61321, Kingdom of Saudi Arabia. (e-mail: mehamid2@yahoo.com)
}

\begin{abstract}
Most aerobic, filamentous, spore-forming Actinomycetes are saprophytes but some are considered pathogens of humans and animals, notable examples are the causal agents of mycetoma. The present study aimed to identify Streptomyces spp. isolated from actinomycetoma cases in Sudan by examining some morphological traits and analyzing the cell wall composition. Nineteen Streptomyces strains isolated from purulent materials of patients with mycetoma (human) or fistulous withers (donkeys) were included in the study. Isolates were tentatively identified as Streptomyces species based on morphological and cultural characteristics. Cell wall analysis of isolates yielded LLdiaminopimelic acid (LL-DAP) which authenticates that the isolates are members of genus Streptomyces. The isolates, though they are Streptomyces, but are variable phenotypes. The study concluded that using few selected criteria, as above, would allow identification of unknown actinomycetoma agent to the genus level. The study also assumes that apparently limitless, numbers of saprophytic Streptomyces enter human or animal skin tissue causing actinomycetoma and perhaps other complications in man and animals.
\end{abstract}

KEYWORDS: Actinomycetoma, Streptomyces species, Madura foot, Sudan

\section{INTRODUCTION}

Mycetoma is a slow destructive infection of cutaneous and subcutaneous tissues, fascia and bone, caused by fungi (eumycetoma) and actinomycetes (actinomycetoma). It is mainly prevalent in tropical rural areas in a belt that matches the Acacia belt in Africa, India, Central and South America $(1,2,3)$. Mycetoma is a major health problem in Sudan notably among rural workers, particularly male farmers, peasant and shepherds. Thorns from Acacia nilotica and other tropical trees, which grow in most parts of tropical Africa, poses serious threat to health by predisposing to mycetoma through direct inoculation of contaminated soil and plant debris to skin.

Actinomycetoma is reportedly caused by Actinomadura madurae, A. pelletieri, Nocardia brasiliensis, $N$. otitidiscaviarum, $N$. transvalensis, Streptomyces sudanesnsis and S. somaliensis $(4,5)$. Most mycetoma cases in Sudan are attributed to $S$. somaliensis $(1,6)$ and $S$. sudanesnsis (5). Currently, the genus Streptomyces includes over 500 validly described species (7, www.ncbi.nlm.nih.gov/Taxonomy/). They form an integral part of soil microbial communities and making up approximately $10 \%$ of total soil microbial flora (8). The majority of research focused on the classification of these saprophytic strains (9, 10), albeit the genus contains few human and plant pathogens $(4,11)$. Streptomyces species are causal agents of diseases in man ( $S$. somaliensis and S. sudanesnsis); animals (Streptomyces species) and plants (Streptomyces scabies) $(6,12$, 13). The cultural and microscopic features of genus Streptomyces, which are commonly used for routine identification, include aerobic growth, gram-positive, non-acid-alcohol-fast, non-motile Actinomycete which forms extensively branched, light yellow substrate mycelia on a variety of media with or without aerial hyphae, with or without diffusible pigments on medium surface $(7,14)$. Cell wall components of Actinomycetes enable rapid qualitative identification of certain Actinomycetes. Such outcome has been believed as "completely satisfactory" $(15,16)$.

The present study was aimed to investigate some growth and morphological features and chemical markers for the identification of Streptomyces species isolated from patients with mycetoma and fistulous withers in Sudan.

\section{MATERIALS AND METHODS Clinical specimens}

Purulent material $(0.5 \mathrm{~mL})$ was collected by needle aspiration from unopened parts of lesions from donkeys with fistulous withers. In case of human mycetoma, grains were taken from deep excision biopsy material of patients, stored in sterile containers and transported to the laboratory where they were either kept on ice for up to 24 hours or used immediately. 


\section{Isolation of Streptomyces species}

Clinical specimens (needle aspirates, grains) were used to inoculate Tryptic Soy agar (TSA; Difco) plates which had been incubated at $37^{\circ} \mathrm{C}$ for up to two weeks. Plates were examined daily until Streptomycete-like colonies were seen, the latter were subcultured onto fresh TSA agar plates which were incubated at $30^{\circ} \mathrm{C}$ for up to 14 days to allow better morphological observation.

Nineteen $(n=19)$ Streptomyces strains have been isolated between 1998 and 2003 from various parts of Sudan from cases of actinomycetoma in human (madura foot) and actinomycetoma in donkeys (fistulous withers). In this study bacteriological and chemotaxonomic characterization was completed on the isolated Streptomyces strains as part of a project that had completed some parts $(5,17,18)$ and other part are underway.

\section{Strains}

The 19 Streptomyces strains are labeled as $S$. somaliensis DSM 40738 ${ }^{\mathrm{T}}$, S. sudanensis DSM 41923 ${ }^{\mathrm{T}}$ (SD504), D501, SD509, DSM41607, Streptomyces spp.: SD511, SD524, SD528, SD534 and DSM40760 (human isolates); SD551, SD552, SD559, SD572, SD573, SD574, SD575, SD576, SD579 (donkey isolates) and $S$. somaliensis DSM 40738T, S. sudanensis DSM 41923T, SD509, DSM41607, DSM41608, DSM41609, Streptomyces spp.: SD511, SD524, SD528, SD534 and DSM40760 (human isolates). S. somaliensis DSM $40738 \mathrm{~T}$ and . sudanensis DSM $41923^{\mathrm{T}}$ served as controls.

\section{Morphological characterization}

Isolates were tentatively identified as member of genus Streptomyces based on selected morphologic criteria $(7,14)$. The clusters of the isolates were recognized based on colony color, substrate and aerial mycelia and the presence of diffusible pigments on TSA media.

\section{Cell wall analysis}

Biomass for chemotaxonomic studies was prepared by growing each strain for 2 weeks at $30^{\circ} \mathrm{C}$ in a $100 \mathrm{ml}$ shake flask containing $25 \mathrm{ml}$ of trypticase soy broth (Difco). The isolates were examined for the presence of the isomers of diaminopimelic acid (DAP) in whole-organism hydrolysates by thin-layer chromatography (TLC) of whole-organism hydrolysates following the procedure described by Staneck and Roberts (19). A standard solution $(10 \mathrm{mM})$ of $\mathrm{A}_{2} \mathrm{pm}$ (Sigma) containing a mixture of LLand meso-DAP isomers was used as a reference. The following markers were also used to control the TLC analysis: S. sudanesnsis (DSM 41923T (SD504) as it reveals LL-DAP; Nocardia farcinica ATCC 3318 which reveals meso-DAP and Dermatophilus congolensis DSM 44180 which reveals neither LL-DAP nor meso-DAP (19).

\section{RESULTS}

The isolates recovered from human and donkey's actinomycetoma cases exhibited different phenotypic features. The initial identification of isolates to cluster and phenotypic groups was done according to growth and colony features characteristics and microscopic appearance (Table 1). The isolates revealed colony morphology of various forms and colors that ranged from grey to blue to grey brown or grey white colonies (Fig. 1).

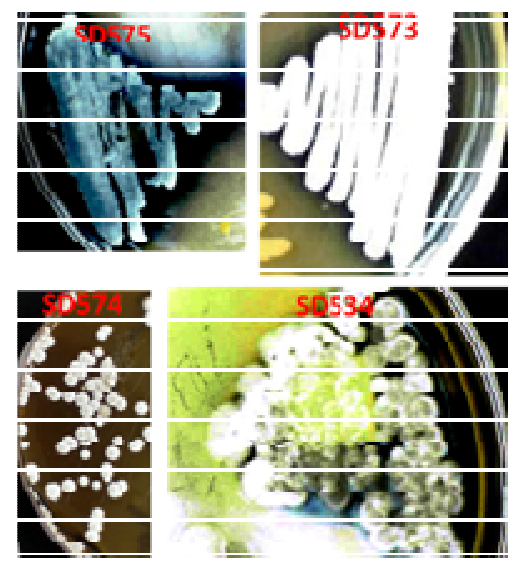

FIGURE 1. Growth of Streptomyces spp. isolated from actinomycetoma cases showing variations in colony morphology which ranged from grey to blue to grey brown or grey white in color. 
These different phenotypic features triggered further studies so as to recognize new species among them. Overall, these isolates had common shared properties of Streptomyces i.e. these were aerobic, Gram-positive, non-acidalcohol-fast, non-motile actinomycete that formed extensively branched substrate
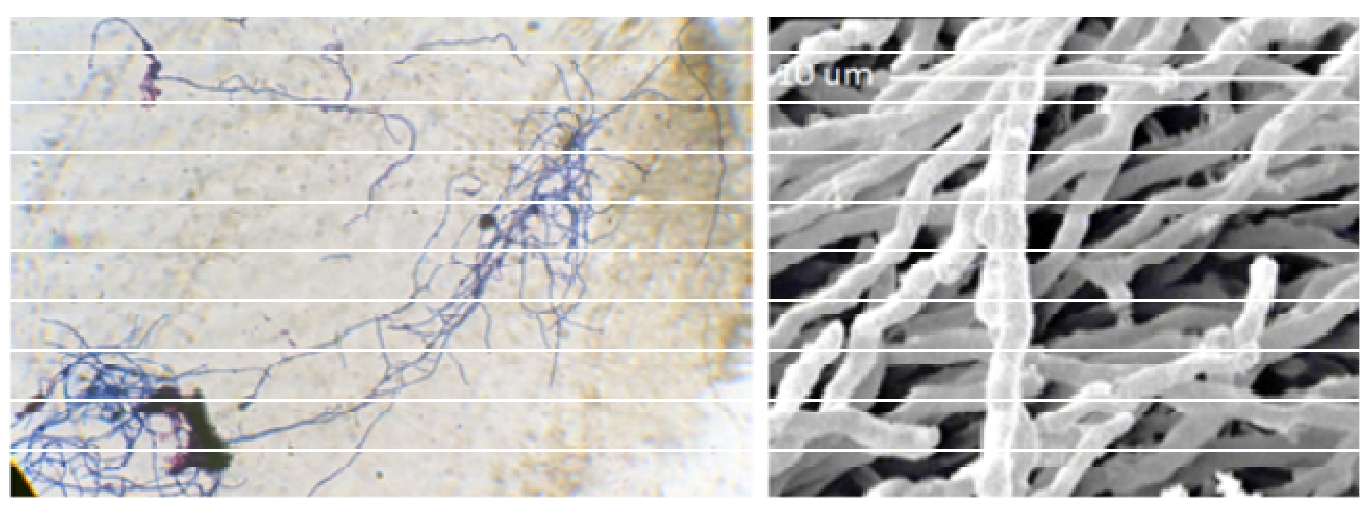

FIGURE 2. Microscopic features of isolated Streptomyces sp. (SD574) (left) and scanning electron micrograph of Streptomyces sp. (SD509) (right). The organism are gram-positive, non-acid-alcohol-fast, forms extensively branched mycelia that are none fragmenting.

In TLC analysis, all the strains were found to contain LL-DAP similar in chromatographic behavior to that produced by the marker species S. sudanesnsis (Fig. 3). Such chemical mycelium on standard media (Fig. 2). The resultant analyzed data revealed that most of the isolates were distinct from both $S$. sudanensis and $S$. somaliensis. These results are in line with the known description of Streptomyces spp. $(4,7)$.

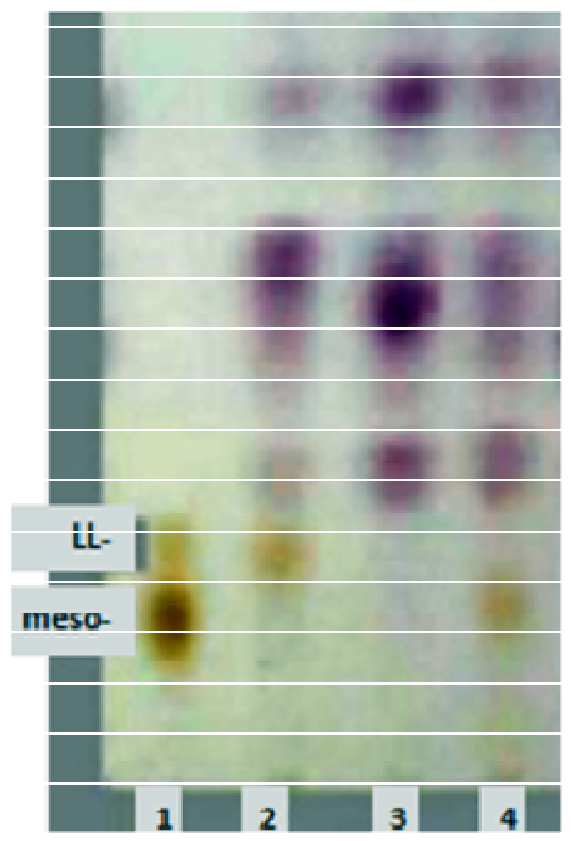

FIGURE 3. TLC analysis of whole cell hydrolysate of Streptomyces isolates. All test strains contain LL- A2pm (lane 2) similar in chromatographic behavior to that produced by the marker strain (lane 1) but distinct from Nocardia farcinica (lane 4) and the negative control (Dermatophilus congolensis; lane 3)

\section{DISCUSSION}

The isolated organisms were tentatively identified as Streptomyces specie on the basis of culture-morphological characteristics (Fig. 1 markers strongly support the identification of the isolates as members of the genus Streptomyces and in accordance with standard descriptions of the genus (7). 
chemotaxonomic feature is a robust technique in differentiating Streptomyces from Nocardia species and from many other species within the order Actinomycetales of the phylum Actinobacteria $(7,14)$.

TABLE 1. MORPHOLOGICAL CHARACTERISTICS OF STREPTOMYCES SPP. (N=19) ISOLATED FROM HUMAN AND DONKEY

\begin{tabular}{|c|c|c|c|c|}
\hline Species & Strain code & $\begin{array}{l}\text { Colony } \\
\text { colour }\end{array}$ & $\begin{array}{l}\text { Reverse colony } \\
\text { colour }\end{array}$ & Aerial hyphae \\
\hline $\begin{array}{l}\text { Streptomyces sudanensis } \\
(\mathrm{n}=4)\end{array}$ & $\begin{array}{l}\text { DSM 41923 } \\
\text { (SD504), D501, } \\
\text { SD509, } \\
\text { DSM41607 }\end{array}$ & Light gray & Light yellow & No aerial hyphae \\
\hline $\begin{array}{l}\text { Streptomyces somaliensis } \\
(\mathrm{n}=1)\end{array}$ & DSM 40738 & Light gray & Light yellow & No aerial hyphae \\
\hline \multirow{14}{*}{$\begin{array}{l}\text { Streptomyces isolates } \\
(\mathrm{n}=14)\end{array}$} & SD 511 & Light gray & Light yellow & No aerial hyphae \\
\hline & SD 534 & White & Yellow & White aerial hyphae \\
\hline & SD 528 & Light gray & Colorless & No aerial hyphae \\
\hline & SD524 & Light gray & $\begin{array}{l}\text { Medium red } \\
\text { brown }\end{array}$ & Light gray aerial hyphae \\
\hline & DSM 40760 & White & $\begin{array}{l}\text { Light yellow } \\
\text { brown }\end{array}$ & White aerial hyphae \\
\hline & SD 551 & $\begin{array}{l}\text { Medium } \\
\text { gray }\end{array}$ & Light brown gray & Medium gray aerial hyphae \\
\hline & SD 552 & Light gray & $\begin{array}{l}\text { Light gray yellow } \\
\text { brown }\end{array}$ & Light gray aerial hyphae \\
\hline & SD 559 & $\begin{array}{l}\text { Light gray } \\
\text { brown }\end{array}$ & Brown gray & Light gray brown aerial hyphae \\
\hline & SD 572 & White & Buff & White aerial hyphae \\
\hline & SD 573 & White & $\begin{array}{l}\text { Medium yellow } \\
\text { brown }\end{array}$ & White aerial hyphae \\
\hline & SD 574 & White & $\begin{array}{l}\text { Medium yellow } \\
\text { brown }\end{array}$ & White aerial hyphae \\
\hline & SD 575 & $\begin{array}{l}\text { Light green } \\
\text { gray }\end{array}$ & Gray green & Light green gray aerial hyphae \\
\hline & SD 576 & White & Buff & White aerial hyphae \\
\hline & SD 579 & White & $\begin{array}{l}\text { Medium yellow } \\
\text { brown }\end{array}$ & White aerial hyphae \\
\hline
\end{tabular}

Abbreviations: T, type strain; DSM, Deutsche Sammlung von ikroorganismen; Inhoffenstraße 7B, 38124

Braunschweig, Germany 
Donkey's fistulous withers and human mycetoma share some pathological and ecological attributes. However, a question remained to be answered: why the infection mainly affects man and donkeys? Some isolates from these lesions have been previously identified as Streptomyces $(5,17,19)$.

The 16S rDNA gene sequence analysis of some strains analyzed so far confirmed that the isolates falls within the phylogenetic clade, which encompasses the genus Streptomyces (data not shown). Studies are underway to further describe these bacteria and assign names to them. This report represents a good evidence to further implicate Streptomyces in the etiology of fistulous withers in donkeys and increases the rate of Streptomyces spp. as causal agents of actinomycetoma in Sudan (6).

Soil saprophytes cause considerable health hazard as demonstrated by a significant, apparently limitless, number of saprophytic

\section{REFERENCES}

1. Mahgoub, E.S. 1985. Mycetoma. Int. J. Derm. 2006; 24: 230-239.

2. Lichon, V. and Khachemoune, A. Mycetoma: A review. American Journal of Clinical Dermatology, 7: 315-321.

3. Fahal, A.H.. Mycetoma: Clinicopathological Monograph. Khartoum University Press, Khartoum. 2006.

4. Trujillo, M.E. and Goodfellow, M. Numerical phenotypic classification of clinically significant aerobic sporoactinomycetes and related organisms. Antonie Van Leeuwenhoek. 2003; 84: 39-68

5. Quintana, E.T., Wierzbicka, K., Mackiewicz, P., Osman, A., Fahal, A.H., Hamid, M.E., Zakrzewska-Czerwinska, J., Maldonado, L.A., Goodfellow, M. Streptomyces sudanensis sp. nov., a new pathogen isolated from patients with actinomycetoma. Antonie Van Leeuwenhoek, 2008; 93: 305-313.

6. Gumaa, S.A. The aetiology and epidemiology of mycetoma. Sudan Med. J. 1994; 32 (Suppl): 14-22.

7. Kämpfer, P. The family Streptomycetceae. pp. 538-604. In: The Prokaryotes, Volume 3: Archaea and Bacteria: Firmicutes, Actinomycetes. $3^{\text {rd }}$ edn. (eds. M Dworkin, phenotypes of Streptomyces. These Streptomyces spp. enter human or animal skin tissue through traumatic injuries, cause actinomycetoma and perhaps other complications in man and animals. DNA-DNA pairing and further phenotypic characterization of these isolates may enable descriptions of new species. This paper has achieved the view of seeking and endorsing the development of simple diagnostic appraoches especially in low income coutries or in laboratory with limited resources.

\section{ACKNOWLEDGEMENTS}

The author is indebted to Prof. M Goodfellow (University of Newcastle); L. Maldonado, E. Quintana (Universidad Nacional Autónoma de México) and Prof. A.H. Fahal (University of Khartoum). Appreciation is extended to Mayami, Salma, Limia and Adil for their help during the research project. The project was supported by Alexander von Humboldt Foundation and the British Council, Khartoum (KHT/991/21/Vet).

E. Rosenberg, K.H. Schleifer and E. Stackebrandt). Springer: New York, USA. 2007.

8. Janssen, P.H. Identifying the dominant soil bacterial taxa in libraries of $16 \mathrm{~S}$ rRNA and 16S rRNA genes. Appl. Envir. Microbiol, 2006; 72: 1719-1728.

9. Xu, C., Wang, L., Cui, Q., Huang, Y., Liu, Z., Zhang, G. and Goodfellow, M. Novel neurotolerant acidophilic Streptomyces species isolated from acidic soils in China: Streptomyces guanduensis sp. nov., Streptomyces paucisporeus sp. nov., Streptomyces rubidus sp.nov. and Streptomyces yangliensis sp. nov. Int. J, Syst. Evol. Microbiol. 2006; 56: 11091115.

10. Labeda, D.P., Goodfellow, M., Brown, R., Ward, A.C., Lanoot, B., Vanncanneyt, M., Swings, J., Kim, S.B., Liu, Z., Chun, J., Tamura, T., Oguchi, A., Kikuchi, T., Kikuchi, H., Nishii, T., Tsuji, K., Yamaguchi, Y., Tase, A., Takahashi, M., Sakane, T., Suzuki, K.I. and Hatano, K. Phylogenetic study of the species within the family Streptomycetaceae. Antonie Van Leeuwenhoek. 2012; 101: 73-104.

11. Joshi, M.V., Bignell, D.R.D., Johnson, E.G., Sparks, J.P., Gibson, D.M. and Loria, R. The AraC/Xyls regulator TxtR modulates thaxtomin biosynthesis and 
virulence in Streptomyces scabies. Mol. Microbiol. 2007; 66: 633-642.

12. Bouchek-Mechiche, K., Gardan, L. Andrivon, D. and Normand, P. Streptomyces turgidiscabies and Streptomyces reticuliscabiei: One genomic species, two pathogenic groups. Int. J. Sys. Evol. Microbiol. 2006; 56: 2771-2776.

13. Welsh, O., Vera-Cabrera, L. and SalinasCarmona, M.C. Mycetoma. Clin. Dermatol. 2007; 25: 195-202.

14. Kumar, Y. and Goodfellow, M. Reclassification of Streptomyces hygroscopicus strains as Streptomyces aldersoniae sp. nov., Streptomyces angustmyceticus sp. nov., comb. nov., Streptomyces ascomycinicus sp. nov., Streptomyces decoyicus sp. nov., comb. nov., Streptomyces milbemycinicus sp. nov. and Streptomyces wellingtoniae sp. nov. Int. J. Syst. Evol. Microbiol. 2010; 60: 769-775.

15. Boone, C., Pine, L. Rapid method for characterization of actinomycetes by cell wall composition. App. Microbiol. 1968; 16: 279-284.

16. Takahashi, Y., Seino, A., Iwai, Y. and Omura, S. Taxonomic study and morphological differentiation of an actinomycete genus, Kitasatospora. Zentralbl Bakteriol. 1999; 289: 265-284.

17. Elzein, S., Hamid, M.E., Quintana, E., Mahjoub, A., Goodfellow, M. Streptomyces sp., a cause of fistulous withers in donkeys. Dtsch Tierarztl Wochenschr. 2002; 109: 442-443.

18. Hamid, M.E. Variable antibiotic susceptibility patterns among Streptomyces species causing actinomycetoma in man and animals. Ann. Clin. Microbiol. Antimicrob. 2011; 6: 10:24.

19. Staneck, J.L. and Roberts, G.D. Simplified approach to identification of aerobic actinomycetes by thin-layer chromatography. App. Microbiol. 1974; 28, 226-231. 